\title{
Behavioral responses of a phoxocephalid amphipod to organic enrichment and trace metals in sediment
}

\author{
J. M. Oakden, J. S. Oliver and A. R. Flegal \\ Moss Landing Marine Laboratories, Moss Landing, California 95039, USA
}

\begin{abstract}
Phoxocephalid amphipods, Rhepoxynius spp., avoided sediments mixed with domestic sewage, or with concentrations of trace metals (zinc and cadmium) which are characteristic of marine sediments at waste-water discharge sites. The amphipods burrowed and swam from fine sands enriched with $15 \%$ sewage, and from sewage-contaminated sediment collected near the White's Point outfall in southern California, USA. They also suffered high $(>50 \%)$ mortality in sediment inoculated with high levels of zinc $\left(610 \mu \mathrm{g} \mathrm{g}^{-1}\right)$ or cadmium $\left(190 \mu \mathrm{g} \mathrm{g}^{-1}\right)$; swam and burrowed from sediments with high and moderate concentrations of either element; and burrowed from sediments with relatively low concentrations of either element. These responses indicate that behavioral avoidance of contaminated sediment may be important in maintaining population patterns of these phoxocephalids, which are often rare or conspicuously absent around large waste discharges
\end{abstract}

\section{INTRODUCTION}

Marine bottom communities around large waste discharges often are highly modified, and characterized by the absence of certain groups of benthic invertebrates, particularly crustaceans and echinoderms (Filice, 1959; Pearson and Rosenberg, 1978; Word, 1979). Among burrowing crustaceans, phoxocephalid amphipods appear to be especially sensitive to waste discharge and sewage-enriched habitats (Word, 1979). Because of its apparent sensitivity, one species, Rhepoxynius abronius, has been the focus of recent efforts to develop a bioassay that might aid in regulating the quality of waste discharges (Swartz et al., 1979; Swartz et al., 1982).

The causes of the low abundance of phoxocephalid amphipods near waste discharges have not been determined. While bioassay studies often concern the lethal effects of sediment contaminants only, many organisms may avoid substrates that cause high mortality. Although habitat selection among amphipods is well known (Meadows and Campbell, 1972), this behavior has not been related to population changes around waste discharges. Nor has it been determined whether phoxocephalids avoid sediments that have been modified by sewage disposal. Such avoidance could be in response to either organic enrichment or elevated concentrations of metals in the sediment.

The possible role of habitat selection was explored in simple laboratory experiments in which phoxocephalids (Rhepoxynius spp.) were given a choice between settling in contaminated or uncontaminated sediments. The specific objectives of the experiments were to determine if phoxocephalids (1) avoid sediments enriched with organic waste; and/or (2) avoid sediments containing elevated concentrations of trace metals (zinc and cadmium). Zinc and cadmium were selected for these experiments because both of these potentially toxic elements are enriched in the sediment perturbed by ocean outfall discharges (Förstner and Wittmann, 1981).

\section{METHODS}

Experimental animals and sediments were collected in Monterey Bay, California, at a water depth of $15 \mathrm{~m}$ by SCUBA divers using acid-cleaned plastic buckets. The sediment was passed through a $0.5 \mathrm{~mm}$ Nytex screen to remove macrofauna, then held in running sea water. Rhepoxynius spp. were collected from the screen residues with a pipette, and were held in aquaria for at least $24 \mathrm{~h}$ before use. Due to the difficulty 
of identifying live phoxocephalids to species, mixtures of approximately $80 \%$ Rhepoxynius abronius - previously identified as Paraphoxus epistomus (Oliver et al., $1980,1982)$ - and $20 \% R$. fatigans - formerly $P$. daboius (op. cit.) - were used. Final identifications were performed after the experiment was concluded.

Aliquots of the Monterey Bay sediment were enriched to 1,5 and $15 \%$ by volume with sewage from the digestion tank of the Watsonville municipal treatment plant. This sewage was relatively high in organics, and relatively low in heavy metals $(0.08 \mu \mathrm{g}$ $\mathrm{Zn} \mathrm{g}^{-1} ; 0.005 \mu \mathrm{g} \mathrm{Cd}^{-1}$ ) and pesticides (unpubl. data, California Water Quality Control Board, Central Coast Region).

Sewage-enriched sediment was also collected in the field with a Van Veen grab at JWPCP Station C-6 (Hershelman et al., 1981), which is $0.5 \mathrm{~km}$ from the Los Angeles County Sanitation District's marine discharge at White's Point. This sediment, which was relatively high in organics, heavy metals $\left(930 \mu \mathrm{g} \mathrm{Zn} \mathrm{g}^{-1} ; 27 \mu \mathrm{g}\right.$ $\mathrm{Cd} \mathrm{g}^{-1}$ ), and pesticides (Word and Mearns 1979), was frozen until use.

Métal-enriched sediment was prepared by adding $\mathrm{Zn}\left(\mathrm{NO}_{3}\right)_{2}$ or $\mathrm{CdCl}_{2}$ to wet, sieved (median $\varnothing=3.2$ ), sand from Monterey Bay and homogenizing it for $30 \mathrm{~min}$ prior to the test period. The concentrations of zinc $\left(31 \pm 5 \mu \mathrm{g}^{-1} \mathrm{~g}\right)$ and cadmium $\left(0.11 \pm 0.03 \mu \mathrm{g}^{-1} \mathrm{~g}\right)$ in the untreated Monterey Bay sediment, which was used as the control sediment, were relatively low; and the additions made the metal concentrations representative to field levels in severely, moderately and slightly polluted habitats. Untreated sediment was processed in the same manner as the enriched sediments. Treatments were generally replicated 3 times.

The concentrations of zinc and cadmium in the sediments were measured after a $0.5 \mathrm{NHCl}$ extraction (Flegal, 1983) by atomic absorption spectrophotometry using a Perkin-Elmer 603 with a deuterium arc background corrector. The $0.5 \mathrm{~N} \mathrm{HCl}$ extraction provided a measure of the relatively labile, biologically available metal concentrations of the sediments, and is similar to the dilute $\mathrm{HCl}$ extractions utilized by Agemian and Chau (1976), Cross et al. (1976), Malo (1977), Luoma and Bryan (1981), and Rice et al. (1981)

The biologically available concentrations of zinc and cadmium in the treated sediments were essentially the same as their near total concentrations. The near total concentrations (measured with an aqua regia digestion) of those elements in the untreated Monterey Bay control sediments were relatively low $10.11 \mu \mathrm{g} \mathrm{Cd} \mathrm{g}^{-1}$, $31 \mathrm{~kg} \mathrm{Zn} \mathrm{g}^{-1}$ ), and $23 \%$ of the cadmium and $45 \%$ of the zinc in them were extracted with $0.5 \mathrm{~N} \mathrm{HCl}$. This lability of added metals is illustrated in Table 1, which shows the concentrations of the treated sediments decreased from 6 to $40 \%$ during the $72 \mathrm{~h}$ experiments.
Table 1. Biologically available ( $0.5 \mathrm{~N} \mathrm{HCI}$ extractable) concentrations of metal-enriched sediments at the start and finish of the $72 \mathrm{~h}$ experiments on the behavioral responses of Rhepoxynius spp. to elevated concentrations of zinc and cadmium in sediments

\begin{tabular}{|cccc|}
\hline Metal & $\begin{array}{c}\text { Elemental concentration }\left(\mu \mathrm{g} \mathrm{g}^{-1}\right) \\
\text { Initial }\end{array}$ & $\begin{array}{c}\text { Percent } \\
\text { Final }\end{array}$ & $\begin{array}{c}\text { loss } \\
\text { Zinc }\end{array}$ \\
\hline \multirow{6}{*}{ Cadmium } & 613 & 490 & 20 \\
& 200 & 175 & 12 \\
& 188 & 175 & 7 \\
& $163^{\circ}$ & 163 & 7 \\
& 51 & 48 & 6 \\
& 190 & 143 & 25 \\
& 5.8 & 4.1 & 29 \\
& 5.6 & 4.1 & 27 \\
24 h incubation & 3.9 & 40 \\
& $6.5^{\circ}$ & & \\
\hline
\end{tabular}

All test containers and plumbing were PVC. Before each experiment, the sediment bowls were acid cleaned and flushed in running sea water for $3 \mathrm{~h}$. Experiments were run on an acid-cleaned plastic water table enclosed in a polyethylene tent. A uni-directional flow-through water system with filtered water from Monterey Bay was used, so temperature and salinity were at ambient levels.

Each experiment involved a choice between 2 types of sediment. Bowls were divided in half by a removable plastic barrier, with one half containing experimental sediment and the control half containing untreated sediment. Sediment was added to the experimental bowls to a depth of $3 \mathrm{~cm}$; a cylindrical screen of $0.5 \mathrm{~mm}$ Nytex which reached above the water surface was fitted around the outside of the dish to prevent amphipod escape; and the dish was placed on the water table. Test containers were oriented on the water table so that both sediments had the same water flow, and control dishes were placed upstream to prevent possible contamination from effluent desorbed from the enriched sediments. After $15 \mathrm{~min}, 1 \mathrm{~cm}$ surface cores were taken for elemental analysis of the initial elemental concentrations, and amphipods were added to the bowls. Experiments ran for $72 \mathrm{~h}$, which is the optimal period for observing habitat selection behavior without possible starvation effects (Oakden, 1981). The amphipods on the sediment surface were then removed; sediment cores were taken for analysis of the final elemental concentrations; and the sediment from each half was sieved to remove all remaining amphipods.

Two variations of this basic design were used. In the first variation, 10 amphipods were placed in each sediment type, and no barrier was placed between the 2 sediments. Those amphipods were able to burrow 
laterally between the 2 sediment types. In the second variation, 15 amphipods were added to the contaminated sediment only, which was physically separated from the control sediment by a $3.5 \mathrm{~cm}$ high plastic barrier. Those amphipods, therefore, had to leave the sediment and swim to get to the other sediment.

\section{RESULTS}

\section{Responses to sewage-enriched sediments}

Amphipods burrowed away from sewage-enriched sediments at most concentrations (Table 2). Avoidance was greater at higher levels of enrichment. There was

Table 2. Rhepoxynius spp. Distribution in $72 \mathrm{~h}, 2$-choice preference experiments with sewage-enriched sediments and untreated sediments

\begin{tabular}{|c|c|c|c|}
\hline \multirow[b]{2}{*}{$\begin{array}{l}\text { Enriched } \\
\text { sediment }\end{array}$} & \multicolumn{3}{|c|}{ Distribution of Rhepoxynius spp. * } \\
\hline & $\begin{array}{l}\text { Enriched } \\
\text { sediment }\end{array}$ & $\begin{array}{l}\text { Untreated } \\
\text { sediment }\end{array}$ & Dead \\
\hline $1 \%$ sewage & 18 & 19 & 2 \\
\hline $5 \%$ sewage & 11 & $27^{\circ}$ & 2 \\
\hline $15 \%$ sewage & 1 & $26^{\bullet}$ & 7 \\
\hline White's Point & 3 & $31^{\circ}$ & 2 \\
\hline \multicolumn{4}{|c|}{$\begin{array}{l}\text { Distribution of Rhepoxynius spp. in untreated sediment } \\
\text { is significantly greater ( } p<0.05 \text {, chi-square test) than in } \\
\text { sewage-enriched sediment }\end{array}$} \\
\hline
\end{tabular}

no measurable preference or avoidance of sediment enriched with only $1 \%$ sewage. Amphipods also burrowed away from sediment collected near the White's Point outfall in southern California, which had a high organic content, and also differed in grain size, metal content and organic composition from the control sediment from Monterey Bay. There was also significantly $(p<0.05$, chi-square test) increased mortality of amphipods in the most sewage-enriched sediment (15\%) relative to the other sediments. These treatments were each replicated twice, and because there was no significant difference between replicates, data from the replicates were combined in Table 2 .

When the amphipods could not burrow away from sewage-enriched sediment, they swam away from it (Table 3). This response contrasted with that in the control experiment, where Rhepoxynius spp. did not swim away from untreated sediment (Table 3). Because there was uneven replication of the swimming experiments, the results are presented in Table 3 as the mean number of amphipods per experimental condition, rather than the total number in all replicates, as in Table 2 .
Table 3. Rhepoxynius spp. Distribution in $72 \mathrm{~h}$ sediment avoidance experiments in which organisms were initially placed in sewage-enriched sediment, and had to swim over a barrier to untreated sediment

\begin{tabular}{|c|c|c|c|c|}
\hline \multirow[b]{2}{*}{ Substrate } & \multicolumn{3}{|c|}{$\begin{array}{l}\text { Mean distribution } \\
\text { of Rhepoxynius spp. }\end{array}$} & \multirow[b]{2}{*}{$\begin{array}{l}\text { Number } \\
\text { of } \\
\text { replicates }\end{array}$} \\
\hline & $\begin{array}{l}\text { No. re- } \\
\text { maining } \\
\text { in en- } \\
\text { riched } \\
\text { sediment }\end{array}$ & $\begin{array}{l}\text { No. } \\
\text { swimming } \\
\text { to un- } \\
\text { treated } \\
\text { sediment }\end{array}$ & $\begin{array}{l}\text { Number } \\
\text { dead }\end{array}$ & \\
\hline \multicolumn{5}{|l|}{ Enriched sediment } \\
\hline $15 \%$ sewage & 6 & $8^{\circ}$ & 1 & 2 \\
\hline White's Point & 6.4 & $5.3^{\circ}$ & 3.3 & 3 \\
\hline Control sediment & 14 & 0 & 1 & 1 \\
\hline \multicolumn{5}{|c|}{$\begin{array}{l}\text { Number of Rhepoxynius spp. swimming from sewage- } \\
\text { enriched sediment to untreated sediment is significantly } \\
\text { greater ( } p<0.05 \text {, chi-square test) than in control experi- } \\
\text { ment }\end{array}$} \\
\hline
\end{tabular}

\section{Responses to metal-enriched sediments}

Amphipods burrowed away from fine sand with elevated zinc concentrations (Table 4). There was over $50 \%$ mortality in sediments with the highest zinc concentration $\left(610 \mu \mathrm{g} \mathrm{g}^{-1}\right)$, and all surviving amphipods

Table 4. Rhepoxynius spp. Distribution in $72 \mathrm{~h}, 2$-choice preference experiments with untreated sediment, and sediment enriched with either zinc or cadmium

\begin{tabular}{|c|c|c|c|c|}
\hline \multirow[t]{2}{*}{ Metal } & \multirow{2}{*}{$\begin{array}{l}\text { Concentration } \\
\text { of enriched } \\
\text { sediment } \\
\left(\mu g g^{-1}\right)\end{array}$} & \multicolumn{3}{|c|}{ Distribution of Rhepoxynius spp. } \\
\hline & & $\begin{array}{l}\text { Enriched } \\
\text { sedi- } \\
\text { ment }\end{array}$ & $\begin{array}{c}\text { Un- } \\
\text { treated } \\
\text { sediment }\end{array}$ & Dead \\
\hline \multirow[t]{4}{*}{ Zinc } & 613 & 0 & $24^{\circ}$ & 29 \\
\hline & 200 & 7 & $45^{*}$ & 6 \\
\hline & 51 & 19 & $39^{\circ}$ & 1 \\
\hline & control & 54 & 61 & 3 \\
\hline \multirow[t]{4}{*}{ Cadmium } & 190 & 0 & $9^{\circ}$ & 47 \\
\hline & 5.8 & 6 & $37^{\circ}$ & 13 \\
\hline & $<0.05$ & 29 & 31 & 0 \\
\hline & control & 54 & 61 & 3 \\
\hline $\begin{array}{l}\text { - Distribut } \\
\text { is signific } \\
\text { metal-enri }\end{array}$ & $\begin{array}{l}\text { of Rhepoxy } \\
\text { ly greater (p } \\
\text { ed sediment }\end{array}$ & $\begin{array}{l}\text { ius spp. in } \\
<0.05 \text {, chi }\end{array}$ & $\begin{array}{l}\text { intreated } \\
\text { quare tes }\end{array}$ & $\begin{array}{l}\text { diment } \\
\text { than in }\end{array}$ \\
\hline
\end{tabular}

were in the untreated sediment after $72 \mathrm{~h}$. Mortality was much less $(10 \%)$ in less enriched $\left(200 \mu \mathrm{g} \mathrm{g}^{-1}\right.$ ) sediment, and $12 \%$ of the amphipods were found living in it after $72 \mathrm{~h}$. There was still a $2: 1$ preference among the amphipods for the untreated sediment over sediment enriched with only $51 \mu \mathrm{g} \mathrm{\textrm {g } ^ { - 1 }}$ of zinc, 
although the mortality in that experiment $(2 \%)$ was comparable to that of the controls $(3 \%)$.

Burrowing avoidance of cadmium was similar to that of zinc (Table 4). At the highest concentration $(190 \mu \mathrm{g}$ $\mathrm{g}^{-1}$ ), there was $84 \%$ mortality after $72 \mathrm{~h}$, and the surviving amphipods were all in the untreated sediment. At $5.8 \mu \mathrm{g} \mathrm{g}^{-1}$, mortality was lower $(23 \%)$, and there was still a significant ( $\mathrm{p}<0.05$, chi-square test) preference for the untreated sediment. However, there was no mortality or significant difference in the distribution of amphipods in sediments with the lowest enrichment level $\left(<0.05 \mu \mathrm{g} \mathrm{g}^{-1}\right)$

Amphipods also actively swam to avoid sediments with intermediate levels of zinc and cadmium when they could not burrow away from it (Table 5). Seventy

Table 5. Rhepoxynius spp. Distribution in $72 \mathrm{~h}$ sediment avoidance experiments in which organisms were initially placed in sediment with elevated concentrations of zinc $\left(188 \mu \mathrm{g} \mathrm{g}^{-1}\right)$ or cadmium $\left(5.6 \mu \mathrm{g} \mathrm{g}^{-1}\right)$, and had to swim over a barrier to untreated sediment

\begin{tabular}{|c|c|c|c|}
\hline Substrate & $\begin{array}{l}\text { Distribution of } \\
\text { No. remain- } \\
\text { ing in } \\
\text { enriched } \\
\text { sediment }\end{array}$ & $\begin{array}{l}\text { epoxynius sp } \\
\text { No. swim- } \\
\text { ming to } \\
\text { untreated } \\
\text { sediment }\end{array}$ & $\begin{array}{c}\text { Num- } \\
\text { ber } \\
\text { dead }\end{array}$ \\
\hline \multicolumn{4}{|l|}{ Enriched sediment } \\
\hline $\begin{array}{l}\operatorname{Zinc}\left(188 \mu \mathrm{g} \mathrm{g}^{-1}\right) \\
\text { Cadmium }\left(5.6 \mu \mathrm{g} \mathrm{g}^{-1}\right)\end{array}$ & $\begin{array}{r}13 \\
7\end{array}$ & $\begin{array}{l}30^{\circ} \\
20^{\circ}\end{array}$ & $\begin{array}{c}2 \\
18\end{array}$ \\
\hline \multicolumn{4}{|c|}{$\begin{array}{l}\text { "Number of Rhepoxynius spp. swimming from metal- } \\
\text { enriched sediment and remaining in the untreated sedi- } \\
\text { ment is significantly greater }(p<0.05 \text {, chi-square test) } \\
\text { than in the control experiment }\end{array}$} \\
\hline
\end{tabular}

percent of the amphipods placed in sediment containing $188 \mu \mathrm{g} \mathrm{g}^{-1}$ of zinc swam to the untreated sediment. Forty percent of the amphipods placed in sediment containing $5.6 \mu \mathrm{g} \mathrm{g}^{-1}$ of cadmium died, and $44 \%$ swam away from it. Both of these results are significantly ( $p<.05$, chi-square test) different from the controls, where amphipods only swam across the barrier occasionally.

\section{DISCUSSION}

Phoxocephalid amphipods actively avoided laboratory sediment enriched with sewage, cadmium, and zinc. They showed a similar avoidance of organicallyenriched fine sand containing Watsonville sewage, which has relatively low concentrations of zinc and cadmium, and sewage-enriched sediment collected near the White's Point discharge, which has relatively high concentrations of pollutants. They also avoided sediment enriched with relatively moderate and low levels of zinc or cadmium, and they experienced relatively high mortality in sediments with higher concentrations of those metals.

Amphipods burrowed and swam from sediments containing sewage or elevated concentrations of trace metals. Because phoxocephalids are well-developed burrowers that swim infrequently both in aquaria and in the field (Oliver et al., 1980; Slattery, in press; Oakden, in press), swimming is probably a more extreme avoidance behavior than burrowing (Oakden, in press). Perhaps in field conditions, amphipods leave the sediment more quickly and swim longer distances after contacting a relatively undesirable sediment.

Among the phoxocephalids, there is considerable interspecific variation in behavior. The species of Rhepoxynius that we studied live at shallower depths than those at the White's Point discharge. However, several deep-water species occur around that site in sediments with relatively high levels of trace metals that were avoided by Rhepoxynius spp. in our laboratory experiments. For example, Heterophoxus oculatus is found around the White's Point discharge in sediments with as much as $19 \mu \mathrm{g} \mathrm{g}^{-1}$ cadmium and $530 \mu \mathrm{g}$ $\mathrm{g}^{-1}$ zinc (unpubl, data, Los Angeles County Sanitation District), and Rhepoxynius bicuspidatus is found at the Orange County discharge in sediments with $6 \mu \mathrm{g} \mathrm{g}^{-1}$ cadmium and $108 \mu \mathrm{g} \mathrm{g}^{-1}$ zinc (unpubl. data, Orange County Sanitation District, 1981). Species of phoxocephalids inhabiting different water depths and sedimentary environments have different sediment preferences (Oakden, in press), and may avoid different concentrations of trace metals as well.

Behavior studies have shown that benthic invertebrates, including phoxocephalids, will inhabit nonoptimal sediment if no other choice is available (Meadows and Campbell, 1972; Erdem and Meadows, 1980; Oakden, in press). The White's Point and adjacent Hyperion discharges are the largest sewage outfalls on the California coast, and they impact a broad region of continental shelf. Because the entire Santa Monica Bay and Palos Verdes Peninsula section of the southern California coast $(\simeq 70 \mathrm{~km})$ have anthropogenically elevated metal levels (Word and Mearns, 1979), phoxocephalids may select suboptimal sediment of necessity.

However, there is no information about the sublethal effects of these choices. Our general understanding of the sublethal effects of waste water discharges on the benthos is fragmented (Eagle, 1981), and the sublethal effects of pollutants on critical aspects of life history, such as mating behavior, pheromone detection, and early development of young, have not been examined.

The levels of zinc and cadmium used in our experiments were similar to concentrations found at various 
distances from a large waste discharge. However, we manipulated only 2 trace metal concentrations, and did not examine their potential synergistic effects. Therefore, our experiments do little to unravel the complexity of effects that occur when a large number of trace metals and other pollutants accumulate in sediments by waste water discharges (Luoma, 1977). It was nonetheless surprising to us that the phoxocephalids respond so dramatically to relatively low enrichments of a single trace metal.

It is difficult to link the behavior observed in laboratory experiments to the large-scale (many $\mathrm{km}^{2}$ ) population and community patterns around waste discharges. Based solely on our experiments, we cannot eliminate habitat selection as a process influencing the distribution and abundance of phoxocephalid amphipods around a large waste discharge such as White's Point. Because phoxocephalids avoid sediments enriched with either organic matter or relatively low levels of trace metals in the laboratory, they may avoid similar enriched sediments in the field. Despite the presence of biological mechanisms for detoxifying pollutants (Bryan, 1976), our studies indicate that sublethal effects of these substances on habitat selection may be as important in establishing and maintaining field populations as the mortality caused by a relatively polluted substrate.

Acknowledgements. The authors would like to thank the Asociación de Biólogos Ambulantes, especially Peter Slattery, and the staff and students of Moss Landing Marine Laboratories, for cooperation and support. This study was funded by EPA grant \# 808772-01.

\section{LITERATURE CITED}

Agemian, H., Chau, A. S. Y. (1976). Evaluation of extraction techniques for the determination of metals in aquatic sediments. Analyst 101: 761-767

Bryan, G. W (1976). Some aspects of heavy metal tolerance in aquatic organisms. In: Lockwood, A. P. M. (ed.) Effects of pollutants on aquatic organisms. Cambridge University Press, New York, p. 7-34

Cross, F. A., Duke, T. W., Willis, J. N. (1970). Biogeochemistry of trace elements in a coastal plain estuary. Distribution of $\mathrm{Mn}, \mathrm{Fe}$ and $\mathrm{Zn}$ in sediments, water and polychaetous worms. Chesapeake Sci. 11: 221-234

Eagle, G. A. (1981). Study of sublethal effects of trace metals on marine organisms - the need for some standardization. Mar. environ. Res. 5: 181-194

Erdem, C., Meadows, P. S. (1980). Influence of mercury on the burrowing behavior of Corophium volutator. Mar. Biol. 56: 233-237
Filice, F. P. (1959). The effect of wastes on the distribution of bottom invertebrates in the San Francisco Bay estuary. Wasman J. Biol. 17: 1-17

Flegal, A. R. (1983). Reference methods for sampling, handling, and measuring the 'biologically available' elemental concentrations of marine sediments. In: Duedall, I. W (ed.) Wastes in the ocean, Vol. VI Near-shore waste disposal. John Wiley, New York

Förstner, U., Wittmann, G. T W. (1981). Metal pollution in the aquatic environment. Springer-Verlag, Berlin

Hershelman, G. P., Schafer, H. A., Jan, T.-K., Young, D. R. (1981). Metals in marine sediments near a large California municipal outfall. Mar. Pollut. Bull. 12: 131-134

Luoma, S. N. (1977). Detection of trace contaminant effects in aquatic ecosystems. J. Fish. Res. Bd Can. 34: 436-439

Luoma, S. N., Bryan, G. W. (1981). A statistical assessment of the form of trace metals in oxidized estuarine sediments employing chemical extractants. Sci. Total Environ. 17: 165-196

Malo, B. A. (1977). Partial extraction of metals from aquatic sediments. Environ. Sci. Technol. 11: 277-282

Meadows, P. S., Campbell, J. I. (1972). Habitat selection by aquatic invertebrates. Adv. mar. Biol. 10: 271-382

Oakden, J. M. (1981). Feeding and habitat selection in five species of central California phoxocephalid amphipods. M. A. thesis, Moss Landing Marine Laboratories, California

Oakden, J. M. (in press). Feeding and sediment selection in five species of central Californian phoxocephalid amphipods. J. Crust. Biol.

Oliver, J. S., Slattery, P. N., Hulberg, L. W., Nybakken, J. W. (1980). Relationships between wave disturbance and zonation of benthic invertebrate communities along a subtidal high-energy beach in Monterey Bay, California. Fish. Bull. U. S. 78: 437-454

Oliver, J. S., Oakden, J. M., Slattery, P. N. (1982). Phoxocephalid amphipod crustaceans as predators on larvae and juveniles in marine soft-bottom communities. Mar. Ecol. Prog. Ser 7: 179-184

Pearson, T., Rosenberg, R. (1978). Macrobenthic succession in relation to organic enrichment and pollution of the marine environment. Oceanogr. mar. Biol. A. Rev. 16: 229-311

Rice, D. L., Tenore, K. R., Windom, H. L. (1981). The effect of detritus ration on metal transfer to deposit-feeding benthos. Mar Ecol. Prog. Ser 5: 135-140

Slattery, P. N. (in press). Life history and ecology of shallowwater infaunal crustaceans, Monterey Bay, California. J. Crust. Biol.

Swartz, R. C., Deben, W. A., Cole, F. A. (1979). A bioassay for the toxicity of sediment to marine macrobenthos. J. Wat. Pollut. Control Fed. 51: 944-950

Swartz, R. C., Deben, W. A., Sercu, K. A., Lamberson, J. O. (1982). Sediment toxicity and the distribution of amphipods in Commencement Bay, Washington, USA. Mar. Pollut. Bull. 13: 359-364

Word, J. Q. (1979). The infaunal trophic index. In: Annual report for the year 1978, Southern California Coastal Water Research Project, Long Beach, California, p. 19-34

Word, J. Q., Mearns, A. J. (1979). Sixty-meter control survey off southern California. TM 229, Southern California Coastal Water Research Project, Long Beach, California

This paper was presented by Professor J. S. Pearse; it was accepted for printing on August 3, 1983 